\title{
HUBUNGAN TINGKAT KECUKUPAN ENERGI DENGAN STATUS GIZI ATLET GULAT PPLP SUMATERA UTARA
}

\author{
Oleh \\ Nurhamida Sari Siregar ${ }^{1}$, Dwi Putra Lasar Dani ${ }^{1}$ \\ ${ }^{1}$ Fakultas Ilmu Keolahragaan, Universitas Negeri Medan \\ Email: nurhamidasari@gmail.com
}

\begin{abstract}
Abstrak
Penelitian ini bertujuan untuk mengetahui hubungan tingkat kecukupan energi dengan status gizi Atlet Gulat PPLP. Desain penelitian adalah cross sectional. Sampel penelitian berjumlah 8 Atlet. Penelitian dilaksanakan di Asrama Atlet PPLP, dengan lama penelitian 5 bulan. Variabel penelitian meliputi tingkat kecukupan energi, IMT dan persen lemak tubuh. Pengumpulan data dilakukan secara primer meliputi data riwayat makan dan aktifitas fisik, berat badan, tinggi badan dan persen lemak tubuh. Instrumen penelitian meliputi food recall dan daftar isian aktifitas fisik $3 \times 24$ jam, timbangan digital, microtoise dan Skinfold Caliper-Thickness. Data dianalisa dengan bantuan program SPPS versi 20. Hasil penelitian menunjukkan yang paling banyak Atlet dengan tingkat kecukupan energi sedang sebanyak6 atlet $(75 \%)$, status gizi normal sebanyak 6 atlet $(75 \%)$ dan persen lemak tubuh kurang sebanyak 5 atlet $(62,5 \%)$. Ada hubungan tingkat kecukupan energi dengan Indeks Massa Tubuh (IMT) Atlet Gulat dengan nilai p $0,004(<0,005)$ dengan korelasi sangat kuat $88 \%$. Tingkat kecukupan energi tidak berhubungan dengan persen lemak tubuh Atlet Gulat dengan nilai p 0,06 (>0,05), dan jika dilihat korelasinya adalah kuat $67,4 \%$.
\end{abstract}

Kata Kunci: Tingkat Kecukupan Energi, IMT, Status Gizi, Atlet Gulat.

\section{A. PENDAHULUAN}

Gulat merupakan salah satu olahraga yang dilakukan oleh dua orang yang saling menjatuhkan atau membanting, menguasai dan mengunci lawan dalam keadaan terlentang dengan menggunakan teknik yang benar sehingga tidak membahayakan keselamatan lawannya (Rubianto, 2004). Gulat merupakan cabang olahraga beladiri yang menitikberatkan pada teknik bantingan dan kuncian pada lawan, dan mengutamakan kekuatan, kelentukan, ketangkasan dan tentunya kesehatan yang prima (PGSI, 1985).

Kesehatan fisik yang prima dapat dimiliki Atlet, salah satunya dengan cara memenuhi kebutuhan nutrisi sesuai dengan kebutuhan atlet tersebut. Asupan nutrisi yang terpenuhi dapat menghasilkan energi yang cukup yang diperlukan Atlet saat berlatih maupun bertanding. Jika sumber energi dalam tubuh tercukupi maka atlet dapat berlatih dan bertanding secara maksimal, sehingga akan bepengaruh terhadap peningkatan prestasi Atlet. 


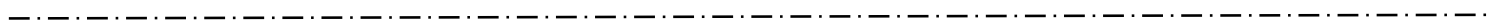

Seorang atlet untuk mencapai prestasi yang maksimal pada suatu cabang olahraga yang digeluti, memerlukan sistem pelatihan yang optimal, termasuk ketersediaan dan kecukupan gizi yang sesuai dengan jenis olahraganya. Untuk meningkatkan prestasi atlet Indonesia ke depan, dirasakan perlu untuk memperbaiki dan menyempurnakan sistem pembinaan dan pelatihan olahraga, terutama dalam melakukan pendekatan dan penerapan Ilmu Pengetahuan dan Teknologi, olahraga termasuk gizi olahraga. Pemenuhan asupan gizi merupakan kebutuhan dasar bagi atlet. Berdasarkan teori olahraga dijelaskan bahwa gizi dan latihan fisik menghasilkan prestasi (Kemenkes, 2014). Zat gizi yang tepat merupakan dasar utama bagi penampilan prima seorang atlet pada saat bertanding. Selain itu, zat gizi ini dibutuhkan pula pada kerja biologik tubuh untuk penyediaan energi pada saat seorang atlet melakukan berbagai aktivitas fisik, misalnya pada saat latihan (training), bertanding dan saat pemulihan baik setelah latihan maupun setelah bertanding (Suniar, 2002).

Makanan Atlet harus mengandung zat gizi sesuai dengan yang dibutuhkan untuk memenuhi kebutuhan energi saat beraktifitas sehari-hari dan olahraga. Makanan yang dikonsumsi harus mengandung zat gizi penghasil energi yang maksimal. Selain itu makanan juga harus mampu mengganti zat gizi dalam tubuh yang berkurang akibat digunakan untuk aktifitas olahraga. Makanan yang mengandung zat gizi seimbang tersebut diharapkan mampu meningkatkan kecukupan energi atlet yang tergambar pada status gizi atlet.

Kebutuhan energi yang diperlukan setiap orang berbeda-beda, bergantung kepada umur, jenis kelamin, berat dan tinggi badan serta berat ringannya aktivitas sehari-hari (Irianto, 2007). Perhitungan dan pemenuhan kebutuhan energi dan zat gizi bagi atlet harus mempertimbangkan jenis olahraga, tahapan pemenuhan gizi untuk periode latihan, kompetisi dan pemulihan. Selain itu perlu juga diperhatikan variasi makanan, kesukaan dan daya terima atlet agar asupannya dapat memenuhi kebutuhan atlet. Energi dihasilkan dari zat gizi makro yaitu karbohidrat, protein dan lemak (Kemenkes, 2014).

Asupan energi seseorang berpengaruh terhadap status gizi orang tersebut. Status gizi baik terjadi bila tubuh memperoleh cukup zat-zat gizi secara efisien, sehingga memungkinkan adanya pertumbuhan fisik, perkembangan otak, kemampuan kerja dan kesehatan secara umum pada tingkat yang maksimal (Almatsier,2001). Status gizi atlet 
merupakan indikator baik-buruknya penyediaan makanan sehari-hari. Status gizi yang baik diperlukan untuk mempertahankan derajat kebugaran dan kesehatan, serta menunjang pembinaan prestasi olahragawan (Irianto, 2007). Berdasarkan latar belakang tersebut, penelitian ini bertujuan untuk mengetahui hubungan tingkat kecukupan energi dengan status gizi Atlet Gulat Pusat Pendidikan dan Latihan Pelajar (PPLP) Sumatera Utara.

\section{B. METODE PENELITIAN}

Desain penelitian adalah penelitian cross sectional, yang dilaksanakan di Asrama PPLP Sumatera Utara (Sumut). Sampel pada penelitian ini adalah Atlet PPLP yang berjumlah 8 orang. Penelitian ini dilaksanakan selama 5 bulan, mulai dari bulan Juni sampai dengan Oktober 2017. Variabel penelitian meliputi variable bebas yaitu tingkat kecukupan energi dan variable terikat yaitu status gizi. Status gizi dilihat berdasarkan Indeks Massa Tubuh (IMT) dan persen lemak tubuh.

Instrumen pada penelitian adalah rekaman diet (food recall) $3 \times 24$ jam, daftar isian aktifitas sehari-hari selama $3 \times 24$ jam, alat timbangan digital, pengukur tinggi badan dengan menggunakan microtoise, persen lemak tubuh diukur menggunakan alat Skinfold Caliper-Thickness dengan ketelitian $0,1 \mathrm{~mm}$. Pengumpulan data food recall dilaksanakan 3 kali selama seminggu pada hari sabtu, minggu dan senin. Pengumpulan data berat badan dan tinggi badan dilakukan sekali pengukuran yang bertujuan untuk mengetahui IMT. Pengumpulan data persen lemak tubuh dilakukan pada pada 4 daerah tubuh yaitu biceps, triceps, subscapula dan suprailliaca.

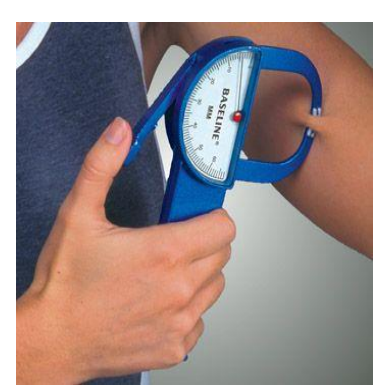

Gambar 1. Biceps Skinfold

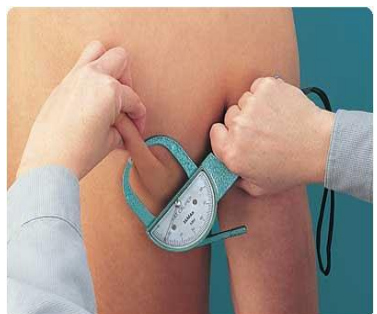

Gambar 3. Subscapular Skinfold

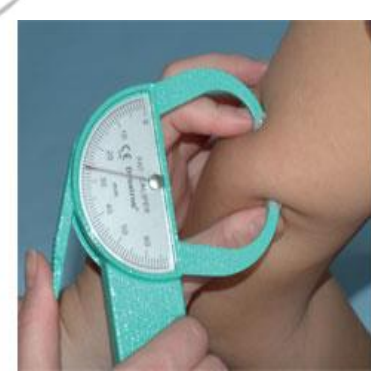

Gambar 2. Triceps Skinfold

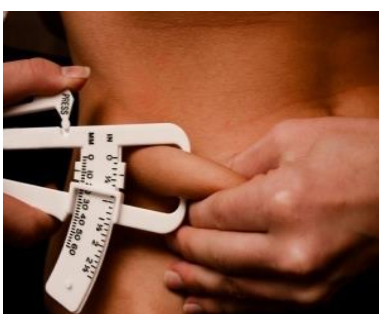

Gambar 4. Suprailliaca Skilnfold 
Data yang telah dikumpulkan dianalisa dengan menggunakan statistik deskriptif dan analitik. Sebelum data dianalisa dilakukan konversi penilaian dari data tingkat kecukupan energi dan status gizi. Statisitik deskriptif untuk analisa data univariat yang bertujuan untuk mengetahui distribusi frekuensi dari variable kecukupan energi dan status gizi. Statistic analitik dipergunakan untuk analisa bivariate melihat hubungan tingkat kecukupan energi dengan status gizi Atlet. Uji korelasi menggunakan spearman rank dengan kepercayaan 95\% dan dianalisa dengan bantuan software SPSS versi 20 for windows.

Tabel 1.

Penggolongan Status Gizi menurut IMT

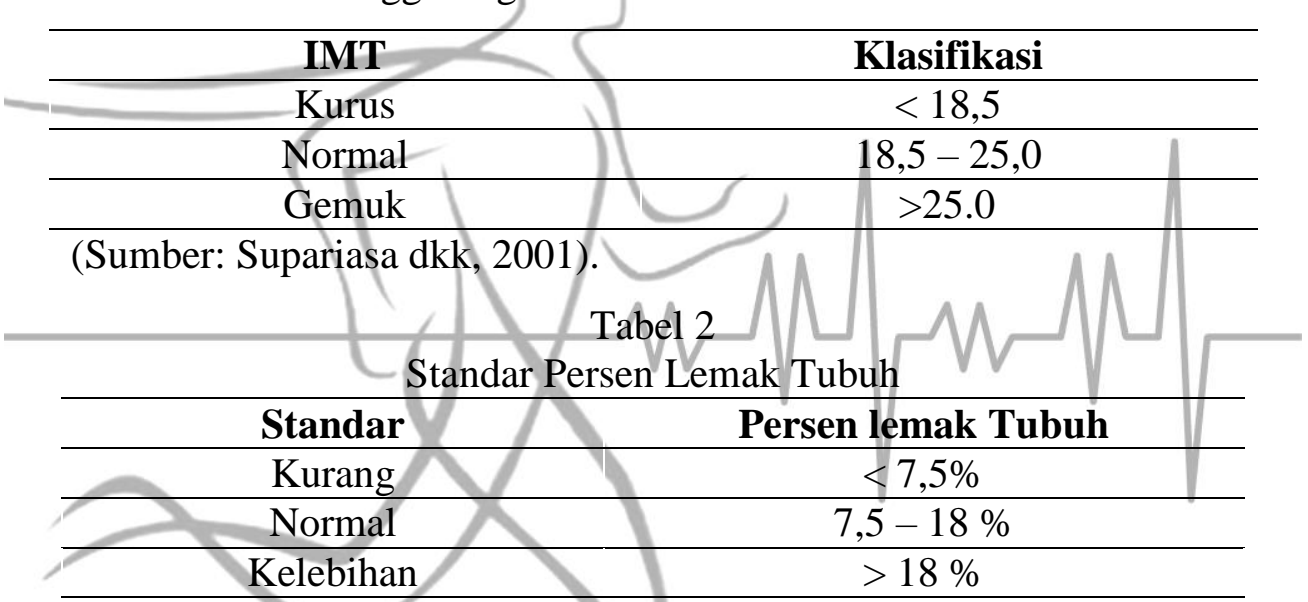

(Sumber : Michelle and Marie, $2009: 62$ )

Tabel 3.

Standar Tingkat Kecukupan Energi

\begin{tabular}{cc}
\hline Standar & Persen Kecukupan Kalori \\
\hline Baik & $\geq 100 \%$ \\
\hline Sedang & $80-99 \%$ \\
\hline Kurang & $70-80 \%$ \\
\hline Defisit & $<70 \%$ \\
\hline
\end{tabular}

(Sumber : Supariasa dkk, 2001)

\section{HASIL DAN PEMBAHASAN}

1. HASIL PENELITIAN

Berdasarkan analisa statitik deskriptif ternyata yang paling banyak Atlet dengan tingkat kecukupan energi sedang, status gizi normal dan persen lemak tubuh kurang. 
Tabel 4 .

Tingkat Kecukupan Energi Atlet Gulat

\begin{tabular}{ccc}
\hline Kecukupan Energi & Jumlah & $(\%)$ \\
\hline Defisit & 1 & 12,5 \\
\hline Kurang & 1 & 12,5 \\
\hline Sedang & 6 & 75,0 \\
\hline Jumlah & $\mathbf{8}$ & $\mathbf{1 0 0 , 0}$
\end{tabular}

Tabel 5.

Status Gizi Berdasarkan IMT Atlet

\begin{tabular}{c|cc}
\hline IMT & Jumlah & $(\%)$ \\
\hline Gemuk & 1 & 12,5 \\
\hline Kurus & 1 & 12,5 \\
\hline Normal & 6 & 75,0 \\
\hline Jumlah & $\mathbf{8}$ & $\mathbf{1 0 0 , 0}$ \\
\hline
\end{tabular}

\section{Tabel 6.}

Status Gizi Berdasarkan Persen Lemak Tubuh Atlet

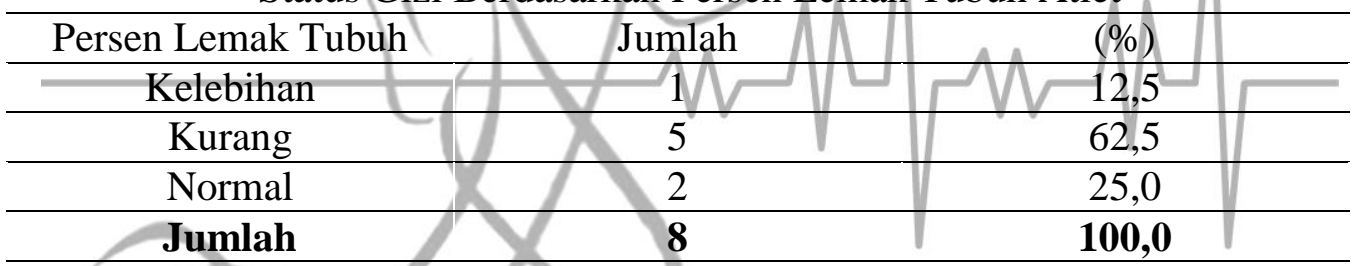

Hasil uji bivariate diketahui bahwa ada hubungan tingkat kecukupan energi dengan Indeks Massa Tubuh (IMT) Atlet Gulat dengan korelasi sangat kuat. Tingkat kecukupan energi tidak berhubungan dengan persen lemak tubuh Atlet Gulat, dan jika dilihat korelasinya adalah kuat.

Tabel 7.

Hasil Uji Bivariate dan Korelasi Antara Tingkat Kecukupan Energi dengan IMT dan Persen Lemak Tubuh

\begin{tabular}{lll}
\hline Variabel & Nilai $\mathrm{p}$ & Korelasi \\
\hline $\begin{array}{l}\text { Tingkat kecukupan energi } \\
\text { dengan IMT }\end{array}$ & 0,004 & $88 \%$ \\
\hline $\begin{array}{l}\text { Tingkat kecukupan energi } \\
\text { dengan persen lemak tubuh }\end{array}$ & 0,067 & $67,4 \%$ \\
\hline
\end{tabular}

\section{PEMBAHASAN PENELITIAN}

Berdasarkan hasil data yang telah diperoleh dapat diketahui bahwa tingkat kecukupan/kebutuhan energi Atlet Gulat PPLP Sumatera Utara tahun 2017 belum terpenuhi atau tercukupi melalui porsi makanan yang dikonsumsi setiap harinya oleh 
atlet. Dalam hal ini dapat dilihat dari standard kecukupan energi Atlet Gulat PPLP Sumatera Utara yang termasuk kategori defisit 1 atlet (12,5\%), yang termasuk kategori kurang 1 atlet (12,5), dan memiliki kategori sedang sebanyak 6 atlet $(75,0 \%)$. Jika hal tersebut tidak diperhatikan, baik pelatih maupun atlet tentunya akan dapat menghambat kamampuan maksimal dalam mengikuti program latihan, karena kurangnya asupan energi ke dalam tubuh.

Melihat kenyataan dari hasil penelitian tersebut menunjukkan bahwa tingkat kecukupan energi atlet gulat PPLP Sumatera Utara adalah sedang dan berlebihan, maka perlu diperhatikan kembali pola komsumsinya dan juga aktivitas fisik yang berlebihan tersebut harus diikuti dengan asupan energi yang baik pula. Hidangan dan makanan bila dikonsumsi dalam jumlah dan cara yang tepat akan menghasilkan keadaan gizi yang sehat, keadaan gizi sehari-hari yang sehat akan meningkatkan perkembangan intelektual, produktivitas seseorang dan mencapai prestasi yang optimal.

berdasarkan IMT yaitu mayoritas berstatus gizi normal, sedangkan selebihnya adalah gemuk dan kurus. Berdasarkan persen lemak tubuh terbagi menjadi 3 kategori yaitu mayoritas berstatus kurang, sedangkan selebihnya adalah normal dan kelebihan.

Hasil analisis uji hubungan menyatakan bahwa terdapat hubungan yang signifikan antara tingkat kecukupan energi dengan status gizi berdasarkan IMT ( $p=$ 0,04), dan memiliki kekuatan hubungan yang sangat kuat $(\mathrm{r}=0,881)$. Hal ini sebanding dengan penelitian Rokhmah, F. dkk (2016) pondok pesantren al-izzah kota batu yang menyatakan terdapat hubungan antara tingkat kecukupan energi dengan status gizi.

Energi merupakan hasil metabolisme protein, lemak dan karbohidrat. Energi diperlukan tubuh untuk pertumbuhan, metabolisme, utilisasi bahan makanan dan aktivitas. Energi yang masuk melalui makanan harus seimbang dengan kebutuhan. Ketidakseimbangan masukan energi dengan kebutuhan yang berlangsung dalam jangka waktu lama dapat menimbulkan masalah gizi. Kekuraangan gizi mengakibatkan menurunnya daya tahan tubuh terhadap penyakit, meningkatkan angka penyakit (mordibitas), mengalami pertumbuhan tidak normal (pendek), tingkat kecerdasan rendah, produktivitas rendah dan terhambatnya organ pertumbuhan reproduksi (Emilia, 2009). 
Cara mendapatkan zat gizi seimbang adalah dengan mengonsumsi makanan sehari-hari yang beranekaragam sehingga kekurangan zat gizi pada jenis makanan yang satu akan dilengkapi oleh susunan zat gizi pada jenis makanan yang lain (Emilia, 2009). Selain itu, upaya untuk menjaga status gizi agar selalu berada dalam kondisi yang optimal adalah dengan berpedoman pada piramida makanan yaitu mengonsumsi makanan sesuai dengan porsi masing-masing individu dan menghindari ketidakseimbangan antara zat gizi.

Status gizi merupakan keadaan tubuh seseorang sebagai akumulasi dari konsumsi makanan selama ini. Status gizi tidak bisa berubah dengan cepat karena tubuh memerlukan waktu untuk memproses zat-zat gizi yang diasup.

Sedangkan hasil analisis uji hubungan menyatakan bahwa tidak terdapat hubungan yang signifikan antara tingkat kecukupan energi dengan status gizi berdasarkan persen lemak tubuh $(\mathrm{p}=0,067)$, dan memiliki kekuatan hubungan yang kuat $(r=0,674)$. Dalam hal ini disebabkan karena tingkat kecukupan energi atlet gulat PPLP Sumatera Utara belum berada pada kategori baik.

Berdasarkan hasil penelitian persen lemak tubuh atlet gulat PPLP Sumatera Utara mayoritas adalah kurang. Ini menandakan bahwasannya tidak ada kelebihan makanan dalam tubuh yang akan disimpan dalam bentuk lemak. Seharusnya atlet dapat menjaga lemak tubuh agar tetap berada pada batas normal. Kekurangan lemak dalam tubuh mampu menimbulkan susah berkonsentrasi, gampang lelah, sering merasa kedinginan, kulit terlihat kering, ketidakstabilan kadar gula darah yang ada didalam tubuh yang dapat berpotensi diabetes dan badan merasa lemas. Kelebihan lemak dalam tubuh juga dapat mengakibatkan obesitas, meningkatkan kadar kolesterol dalam darah, meningkatkan dampak kanker, sembelit dan kerusakan otak.

Kelebihan berat badan sebenarnya tidak selalu bermasalah, asalkan kadar lemak tubuh masih dalam keadaan normal. Bahkan pada atlet tertentu, kelebihan berat badan beradasarkan pengkuran tinggi dan berat badan sering dijumpai, tetapi tidak mengganggu prestasinya. Sekarang ada konsep baru mengenai berat badan ideal, yaitu berat badan cukupan atau berat badan yang dianggap paling tepat untuk cabang olahraga tertentu, yang terpenting adalah tebal lemak di bawah kulit masih dalam batas normal (Irianto, 2007:155). 
Pada penelitian ini di peroleh hasil untuk masing-masing penilaian tingkat kecukupan energi dan status gizi atlet gulat PPLP Sumatera Utara, keterangan atlet sebagai berikut : Roling berusia 17 tahun, dengan pengukuran IMT diperoleh nilai 17,93 yang termasuk kedalam kategori kurus dan pengukuran persen lemak tubuh diperoleh nilai persentase 4,8 termasuk kedalam kategori kurang. Dalam hal ini, tentunya atlet belum berada pada status gizi yang baik. Jika dilihat dari perhitungan angka kecukupan gizi yang meliputi asupan dan kebutuhan energi, maka diperoleh nilai asupan energi sebesar 3749 kalori dan untuk kebutuhan energinya sebesar 4280 kalori. Hal ini terlihat jelas kenapa atlet tersebut belum memiliki status gizi baik dikarenakan kebutuhan energi lebih besar dari pada asupan energi. Jadi setiap asupan yang dikonsumsi atlet tersebut akan habis terpakai dan tidak akan terjadi nya proses penyimpanan cadangan energi didalam tubuh, sehingga untuk memenuhi kecukupan gizi tersebut diambil melalui sumber cadangan energi berupa lemak yang akan diubah menjadi energi. Jika hal tersebut terus menerus terjadi maka status gizi atlet akan menurun dan akan mempengaruhi kondisi fisiknya.

\section{KESIMPULAN}

1. Tingkat kecukupan energi berhubungan secara signifikan terhadap IMT Atlet Gulat PPLP Sumatera Utara

2. Tingkat kecukupan energi tidak berhubungan secara signifikan terhadap persen lemak tubuh Atlet Gulat PPLP Sumatera Utara

\section{Daftar Pustaka}

Almatsier, Sunita. (2001). Prinsip Dasar Ilmu Gizi. Jakarta; Gramedia Pustaka Utama. Asmira, Sutarto. (1980). Ilmu Gizi SGO. Departemen Pendidikan dan Kebudayaan. Jakarta : Rineka Cipta

Azrimaidaliza., \& Purnakarya, I. (2011). Analisis Pemilihan Makanan pada Remaja di Kota Padang, Sumatra Barat. Jurnal Kesehatan Masyarakat Nasional, Vol. 6, No.1.

Budi, Prasojo. (2007). Faktor - faktor yang Berhubungan dengan Status Gizi pada Pemain Persatuan Sepakbola Indonesia Semarang (PSIS) Yunior. Jurnal Kedokteran Undip.

Dahlan, Sopiyudin. (2013). Statistik untuk kedokteran dan kesehatan. Jakarta: Salemba Medika

Dunford, Marie. (2009). The Athlete's Guide to Making Weight. United States of America: United Graphics.

Emilia, E. (2009). Pendidikan Gizi Sebagai Salah Satu Sarana Perubahan Perilaku Gizi pada Remaja. Jurnal Tabularasa PPS Unimed, Vol. 6, No. 2. 
Emilia, E. (2009). Pengetahuan, Sikap dan Praktek Gizi pada Remaja dan Implikasinya pada Sosialisasi Perilaku Hidup Sehat. Media Pendidikan Gizi Kuliner, Vol. 1, No.1.

Erawan, B. (2010). Modul Kuliah Gulat. Bandung : FPOK UPI

Fink, H. Burgoon, L dan Mikeskey, Alan. (2006). Practical Application in Sports Nutrition. USA: Jones and Barlett Publishers.

Gede Karyamita, Ni Luh dan Tresna Adhi, Kadek. (2012). Tingkat Kecukupan Gizi, Aktivitas Fisik, Dan Status Gizi Atlet Sepak Bola Remaja Putra Sekolah Menengah Atas (SMA) Negeri Di Kota Denpasar Tahun 2011. Jurnal Ilmiah Kedokteran, Vol 43 Nomer 2, Mei 2012.

Irianto, Djoko. (2007). Panduan Gizi Lengkap Keluarga dan Olahragawan. Yogyakarta: Andi Offset.

Latief, Dini. (2000). Pedoman Pelatihan Gizi Olahraga untuk Berprestasi. Jakarta; Depkes RI.

Mustamin, Kunaefah Uun dan Ayu SD. (2010). Tingkat Pengetahuan Gizi, Asupan Dan Status Gizi Atlet Di Pusdiklat Olahraga Pelajar Sudiang Kota Makassar. Jurnal Media Gizi Pangan, Vol IX, Edisi 1, Januari - Juni 2010.

Notoatmodjo, Soekidjo. (2010). Metodologi Penelitian Kesehatan. Jakarta: PT Rineka Cipta.

PGSI. (1985). Seperempat Abad Gulat Di Indonesia. Jakarta :Persatuân Gulat Seluruh Indonesia Cabang Jakarta Barat.

Rokhmah F, Muniroh L dan Nindya TS. (2016). Hubungan Tingkat Kecukupan Energi Dan Zat Gizi Makro Dengan Status Gizi Siswi Sma Di Pondok Pesantren Al-Izzah Kota Batu. Media Gizi Indonesia Vol. 11, No. 1: hlm. 94-100.

Sjahmien, Moedji. (1982). Ilmu Gizi. Jakarta : Bhratara Karya Aksara

Suharsimi, Arikunto. (2016). Prosedur Penelitian Ilmiah Suatu Pendekatan Praktik. Jakarta: PT Rineka Cipta.

Suniar, L. (2002). Dukungan Zat-zat Gizi untuk Menunjang Prestasi Olahraga. Jakarta: Kalamed

Supariasa, I Dewa Nyoman, dkk. (2001). Penilaian Status Gizi. Jakarta: EGC.

Zuhdy, Nabila. (2015). Hubungan Pola Aktivitas Fisik Dan Pola Makan Dengan Status Gizi Pada Pelajar Putri Sma Kelas 1 Di Denpasar Utara. Tesis. Universitas Udayana Denpasar. 